\title{
ARCHITECTURAL ACCULTURATION IN THE RESIDENCE OF BUDHI SANTOSO
}

\author{
${ }^{1}$ Fransnino. ${ }^{2}$ Yenny Gunawan, ST., M.A. \\ ${ }^{1}$ Student in the Bachelor's (S-1) Study Program in Architecture at \\ Parahyangan Catholic University \\ ${ }^{2}$ Senior lecturer in the Bachelor's (S-1) Study Program in Architecture at \\ Parahyangan Catholic University
}

\begin{abstract}
In the Colonial Era, Dutch architects came to Indonesia and designed buildings based on their European expertise. They adapted to the factor of the tropical climate and indigenous cultural elements as a source of developing the process of architectural acculturation. The residence of Budhi Santoso in Yogyakarta is one of the products resulting from the acculturation between Dutch colonial architecture and the local wisdom and skills of Javanese culture. Architectural acculturation is an important topic that requires further study to contribute to the wealth of cultural knowledge, academic vocabulary as well as the variety of Indonesian architectural styles.The research method consists of qualitative research while the data processing has been obtained from studying the relevant background literature, direct observation, taking measurements, recording data in the shape of photographs and conducting interviews with the owner, $\mathrm{Mr}$ Budhi Santoso himself. The data were subjected to analysis using the comparative method by way of a comparison between Dutch and Javanese architecture. This analysis employs a theory derived from the study of background literature, namely Francis D.K. Ching's theory concerning form, space and order to draw conclusions from the research study of cultural acculturation as observed in this residence.The conclusion indicates that Budhi Santoso's residence is the product of a form of cultural acculturation between Dutch and Javanese architecture viewed from various angles, including the aspects of site/location, mass form, spatial order (lay-out), the elements of structural and non-structural scope and ornaments. These aspects have been affected by certain dominant features from one of the architectural styles, or else they have received the impact from a mixture between the two styles mentioned, leading to a new type of hybrid architecture.
\end{abstract}

Keywords: Acculturation, Dutch Architecture, Javanese Architecture

\section{AKULTURASI ARSITEKTUR PADA RUMAH TINGGAL BUDHI SANTOSO}

\author{
${ }^{1}$ Fransnino. ${ }^{2}$ Yenny Gunawan, ST., MA. \\ ${ }^{1}$ Mahasiswa S1 Program Studi Arsitektur Universitas Katolik Parahyangan. \\ ${ }^{2}$ Dosen Pembimbing S1 Program Studi Arsitektur Universitas Katolik Parahyangan.
}

${ }^{1}$ Corresponding Author:fransninoc@gmail.com 


\begin{abstract}
Abstrak- Belanda datang ke Indonesia membawa budaya asing dan pengetahuan yang mempengaruhi perkembangan arsitektur Indonesia dilihat dari peninggalan arsitekturnya yang menjadi bukti perjalanan sejarah. Arsitek asing mendesain bangunan di Indonesia mengadaptasi faktor iklim dan unsur-unsur budaya lokal sebagai sumber pengembangan sehingga membentuk proses akulturasi arsitektur. Rumah Tinggal Budhi Santoso di Yogyakarta merupakan salah satu produk akulturasi arsitektur kolonial Belanda dengan kearifan lokal budaya Jawa. Metode yang digunakan dalam penelitian ini adalah penelitian kualitatif dengan cara memperoleh data dari studi literatur, pengamatan secara langsung, melakukan pengukuran, perekaman data berupa foto dan wawancara dengan pemilik bangunan yaitu Bapak Budhi Santoso. Setelah seluruh data didapatkan maka data tersebut kemudian dianalisa dengan metode komparatif dengan cara membandingkan objek penelitian yaitu arsitektur Belanda dan arsitektur Jawa. Analisa tersebut menggunakan teori yang didapatkan dari studi literatur yaitu teori bentuk, ruang, dan tatanan oleh Francis D.K. Ching untuk mendapatkan kesimpulan dari penelitian ini tentang akulturasi arsitektur pada Rumah Tinggal Budhi Santoso.Dari penelitian ini didapatkan kesimpulan bahwa Rumah Tinggal Budhi Santoso yang berada di kota Yogyakarta merupakan produk hasil wujud akulturasi arsitektur antara arsitektur Belanda dan arsitektur Jawa yang ditinjau dari berbagai aspek yaitu tapak, bentuk massa, tata ruang, elemen pelingkup (struktural dan non struktural) dan ornamen. Aspek-aspek tersebut mendapatkan pengaruh dimana terdapat aspek yang dominan dari salah satu arsitektur ataupun mendapatkan pengaruh dari campuran kedua arsitektur sehingga membentuk arsitektur yang baru.
\end{abstract}

Kata kunci: Akulturasi, Arsitektur Belanda, Arsitektur Jawa, Rumah Tinggal Budhi Santoso

\title{
1 PENDAHULUAN
}

\subsection{LATAR BELAKANG}

Perubahan terjadi pada pada arsitektur di Indonesia saat budaya Belanda datang dimana arsitek-arsitek asing yang tinggal di Indonesia banyak membangun bangunan dengan gaya arsitektur tempat asalnya yaitu Belanda. Akan tetapi seiring perkembangannya, arsitekarsitek tersebut merubah pandangan mereka akan arsitektur dengan yang harus sesuai dengan konteks tempat dengan memperhatikan kondisi lingkungan. Selain itu perlu arsitek-arsitek asing berpikir bahwa perlu adanya unsur-unsur lokal yang dipadukan dengan arsitektur mereka sehingga menciptakan arsitektur baru.

Akulturasi arsitektur banyak terjadi di kota-kota besar Indonesia khususnya di Kota Yogyakarta. Rumah Tinggal Budhi Santoso merupakan salah satu produk akulturasi arsitektur yang muncul pada zaman kolonial di awal abad 19. Perpaduan gaya arsitektur Belanda yang mengalami adaptasi iklim setempat dan memuncul kearifan lokal arsitektur Jawa di dalam konsep perancangannya yang diterjemahkan pada gubahan arsitektural bangunan tersebut.

Akulturasi menjadi hal penting yang patut diteliti dengan lebih melihat konsep dan makna dibalik gaya arsitektur tersebut dimana terdapat perpaduan dari dua arsitektur yang berbeda. Proses akulturasi khususnya akulturasi arsitektur akan menimbulkan dampak positif dimana terciptanya kebudayaan baru yang memiliki manfaat serta menambah perbendaharaan kebudayaan serta ragam jenis arsitektur Indonesia. Selain itu dapat menambah pengetahuan serta wawasan bagi akademik dalam bidang arsitektur di Indonesia.

\subsection{RUMUSAN MASALAH}

(1) Bagaimanakah wujud akulturasi arsitektur pada bangunan Rumah Tinggal Budhi Santoso di Yogyakarta? 


\subsection{TUJUAN}

(1) Memahami lebih dalam tentang akulturasi arsitektur. (2) Mengetahui perbedaan arsitektur Belanda dengan arsitektur Jawa. (3) Mengetahui wujud akulturasi arsitektur pada bangunan Rumah Tinggal Budhi Santoso di Yogyakarta.

\subsection{METODE PENELITIAN}

Jenis penelitian yang digunakan adalah penelitian kualitatif. Penelitian ini menggunakan teknik observasi lapangan dengan metode deskriptif dan metode komparatif.

\subsubsection{TEMPAT DAN WAKTU PENELITIAN}

Tempat Penelitian: Rumah Tinggal Budhi Santoso, Jalan Cik Di Tiro No. 16, Gondokusuman, Daerah Istimewa Yogyakarta 55223

Waktu Peneltiain: Februari 2016 - Mei 2016

\subsubsection{TEKNIK PENGUMPULAN DATA}

(a) Studi literatur mengenai teori akulturasi dalam arsitektur, teori arsitektur Belanda dan teori arsitektur Jawa.

(b) Survei/Observasi dengan cara mengamati objek secara langsung, pendataan berupa pengukuran, perekaman data seperti dokumentasi foto/video.

(c) Wawancara dengan pemilik bangunan Rumah Tinggal Budhi Santoso untuk mendapatkan informasi yang lebih dalam terutama mengenai sejarah bangunan.

\subsubsection{ALAT PENGUKUR DATA}

Alat pengukur data yang digunakan khususnya di lapangan yaitu meteran atau digital meter, alat tulis berupa pensil, pulpen, dan kertas serta kamera dan alat perekam suara.

\subsubsection{TEKNIK ANALISIS DATA}

Teknik analisis data dimulai dari pengumpulan data-data terlebih dahulu baik dari literatur mengenai teori akulturasi maupun dari survei/observasi lapangan secara langsung dan wawancara dengan pemililik bangunan yaitu Bapak Budhi Santoso. Data-data yang diperoleh kemudian di analisa dengan cara membandingkan antara arsitektur Belanda dan arsitektur Jawa terkait studi literatur. Cara membandingkan dengan melihat teori arsitektur Belanda dan arsitektur Jawa yang memiliki data kemudian di analisa dengan data observasi untuk memperoleh sintesa. Sintesis ditinjau dari teori bentuk, ruang, dan tatanan oleh D.K. Ching.

\section{KAJIAN TEORI AKULTURASI ARSITEKTUR BELANDA DAN ARSITEKTUR JAWA}

\subsection{TEORI ARSITEKTUR}

Arsitektur merupakan ilmu dan seni dalam perencanaan dan perancangan suatu lingkungan binaan yang memiliki cakupan dari yang luas (makro) seperti kawasan kota dan lansekap hingga kecil (mikro) seperti bangunan dan interior. Teori yang paling mendasar mengenai arsitektur 
berasal dari Marcus Vitruvius Polio dalam bukunya yang berjudul The Ten Books of Architecture. Vitruvius menyimpulkan 3 aspek dasar yang harus dipenuhi dalam arsitektur, yaitu Firmitas (kekuasaan), Utilitas (kenyamanan), dan Venustas (keindahan).

\subsection{BENTUK, RUANG, DAN TATANAN (D.K. CHING)}

\subsubsection{BENTUK}

Bentuk merupakan istilah yang memiliki wujud fisik dengan penampilan luar yang dapat dilihat dan dikenali. Bentuk memiliki wujud dasar/bentuk dasar, ukuran, warna, dan tekstur. Bentuk juga memiliki sifat-sifat yang saling terkait yang menentukan dan komposisi suatu gubahan arsitektural seperti posisi, orientasi, dan innersia visual (D.K. Ching, 1996).

\subsubsection{RUANG}

D.K. Ching (1996) menyebutkan bahwa organisasi ruang dapat dibagi menjadi 5 bagian, yaitu organisasi terpusat, organisasi linier, organisasi radial, organisasi terklaster, organisasi grid.

\subsubsection{ELEMEN PELINGKUP}

Dalam Archetypes in Architecture, Thomas Thiis-Evensen (1987) berpendapat bahwa elemen pelingkup dasar dalam arsitektur dapat dibagi menjadi tiga elemen berdasarkan pengalaman ruang yang dapat dirakasan yaitu atap, dinding, dan lantai. Ketiga elemen tersebut membentuk hubungan antar ruang seperti ruang dalam dan ruang luar.

\subsubsection{PRINSIP PENYUSUNAN}

Prinsip penyusunan merupakan prinsip dasar yang digunakan untuk menciptakan bentuk tatanan dalam suatu gubahan arsitektural sehingga menciptakan tatanan yang memiliki kesatuan dan harmonis. Prinsip-prinsip tersebut antara lain sumbu, simetri, hirarki, irama/pengulangan, datum, dan transformasi.

\subsection{AKULTURASI}

Akulturasi merupakan suatu proses yang berkaitan dengan perpaduan dua kebudayaan atau lebih yang saling mempengaruhi satu sama lain tanpa menghilangkan esensi atas budayanya itu sendiri yang menciptakan arsitektur dengan konsep yang baru. Akulturasi dapat terjadi dalam berbagai bentuk, antara lain substitusi, sinkretisme, adisi, dekulturasi, orijinasi, dan penolakan.

\subsection{ARSITEKTUR BELANDA}

\subsubsection{TAPAK}

Arsitektur Belanda dalam perancangan blok kota mengenal tata letak bangunan terhadap tapak yaitu tata letak bangunan terbuka dan tata letak bangunan tertutup. Beberapa negara di Eropa khususnya Belanda menerapkan konsep gardencityyang memiliki tata letak bangunan menghadap jalan dan mempunyai ruang terbuka pada tapak yang dimanfaatkan untuk area hijau. Tata letak bangunan memiliki orientasi ke arah jalan dengan memperhatikan urban elements khususnya corners atau bangunan di kaveling sudut. 


\subsubsection{BENTUK MASSA}

Atap pada arsitektur Belanda memiliki sudut kemiringan yang relatif curam berkisar 30 sampai 60 derajat sebagai upaya penyikapan terhadap iklim dan lingkungan. Pada umumnya, atap bangunan arsitektur Belanda sering kali menjadikan suatu unsur volume yang menunjukkan jati diri bangunan. Sebagian besar bentuk bangunan arsitektur Belanda memiliki satu massa bangunan yang berdiri sendiri yang megah dan formal.

\subsubsection{TATA RUANG}

Penataan ruang pada arsitektur Belanda pada umumnya memiliki pola ruang yang simetris. Rumah tinggal dalam arsitektur Belanda pada umumnya memiliki pintu masuk utama berada di tengah bangunan dan ruang tengah bangunan merupakan koridor/sirkulasi sehingga pola ruang yang terjadi terbagi dua sama besar. Tata ruang dalam arsitektur Belanda memiliki kesan formal pada susunan ruangnya serta terdapat kejelasan pada pembagian ruangannya.

\subsubsection{ELEMEN PELINGKUP}

Bangunan dalam arsitektur Belanda pada umumnya menggunakan atap perisai dengan struktur kuda-kuda kayu. Bagian badan bangunan menggunakan sistem dinding pemikul. Pintu memiliki dimensi yang tinggi dengan skala monumental dan jendela memiliki dimensi yang tinggi pula dengan material kayu dan kaca. Lantai pada bangunan memiliki elevasi yang tinggi biasanya tedapat beberapa pijakan anak tangga sebelum masuk ke lantai dasar bangunan.

\subsubsection{ORNAMEN}

Ragam hias pada arsitektur Belanda sebagian besar merupakan hiasan yang konstruksional sehingga menjadi elemen yang tidak dapat dilepaskan dari bagian bangunan. Biasanya ragam hias tersebut terbuat dari bahan beton atau batu bata yang permanen dan tidak memiliki arti atau makna khusus. Contohnya, windwijzer, gevel, gabbletoppen, nokacreterie, dormer, kolom, balustrade, pedestal.

\subsection{ARSITEKTUR JAWA \\ 2.5.1 TAPAK}

Kehidupan masyarakat Jawa sangat erat dengan filosofi dan kepercayaan ataupun mitosmitos dalam setiap aktivitas yang dilakukan. Tapak merupakan salah satu unsur yang berpengaruh terhadap penataan terutama rumah tradisional masyarakat Jawa yang yang erat kaitannya dengan kepercayaan terhadap arah mata angin. Orientasi rumah tradisional masyarakat Jawa terhadap tapak pada umumnya menggunakan sumbu kosmis dari arah utara-selatan tempat tinggal Ratu Kidul, dewi Laut Selatan dan dewi pelindung Kerajaan Mataram. Orientasi terhadap sumbu kosmis dari arah barattimur digunakan sebagai unsur dari bagian keraton bukan untuk orientasi terhadap tapak rumah tinggal rakyat biasa. Dasar perencanaan rumah tinggal masyarakat Jawa memperhatikan pedoman dengan pengertian sumbu kosmis (Heinz Frick, 1997:84-85).

\subsubsection{BENTUK MASSA}

Bentuk Massa rumah tinggal masyarakat Jawa dapat terbagi menurut tipologi dan bentuk bagian-bagiannya antara lain, panggangpe, kampung, limasan, tajug, dan joglo. Bentukan atap 
berhubungan pada tahapan penyucian terkait dengan pendudukan sosial penghuni masyarakat Jawa.

\subsubsection{TATA RUANG}

Suatu perumahan tradisional masyarakat Jawa dalam struktur tata ruangnya dibagi dua yaitu rumah induk dan rumah tambahan. Rumah induk terdiri dari bagian-bagian berikut (Heinz Frick, 1997:86) antara lain, pendopo, dalemagung, sentong, pringgitan, tratag, gandok, dan gadri.

\subsubsection{ELEMEN PELINGKUP}

Elemen pelingkup arsitektur Jawa dibedakan menjadi tiga bagian yaitu atap, dinding, dan lantai. Pada bagian atap, atap rumah tradisional Jawa dirakit dengan empyak dan biasanya tidak menggunakan plafon sehingga konstruksi atap dapat terlihat. Pada bagian dinding terdapat 3 macam jenis yaitu gebyog (kayu), gedheg (bambu), dan patangaring (kayu dan bambu). Pintu dan jendela juga terdapat 2 macam jenis yaitu inep siji dan inep loro serta lantai yang biasanya hanya terbuat dari urugan tanah atau pasir dan dapat ada juga yang ditambah dengan keramik. Sistem struktur arsitektur Jawa menggunakan sistem struktur rangka dimana saka(tiang) merupakan struktur utama sebagai penopang atau penahan utama konstruksi atap.

\subsubsection{ORNAMEN}

Hiasan pada bangunan rumah Jawa tradisional pada dasarnya ada dua macam, yaitu hiasan yang konstruksional dan hiasan yang tidak konstruksional. Hiasan konstruksional ialah hiasan yang jadi satu dengan bangunannya sedangkanhiasan yang tidak konstruksional ialah hiasan bangunan yang dapat terlepas dari bangunannya dan tidak berpengaruh apa-apa terhadap konstruksi bangunannya. Ragam hias Jawa meliputi ragam hias flora, fauna, alam, agama dan lainnya.

\section{ANALISA AKULTURASI ARSITEKTUR PADA RUMAH TINGGAL BUDHI SANTOSO}

Analisa akulturasi arsitektur pada Rumah Tinggal Budhi Santoso dibahas dari beberapa aspek; tapak, bentuk massa, tata ruang, elemen pelingkup, dan ornamen. Analisa tersebut ditinjau berdasarkan kajian teoritik terkait dengan arsitektur Belanda dan arsitektur Jawa dengan menggunakan prinsip dasar arsitektur oleh D.K. Ching tentang bentuk, ruang, dan tatanan.

\subsection{TAPAK RUMAH TINGGAL BUDHI SANTOSO \\ 3.1.1 ORIENTASI}

Orientasi pada Rumah Tinggal Budhi Santoso serupa dengan orientasi rumah Belanda dimana bangunan dalam arsitektur Belanda memiliki orientasi muka depan bangunan ke arah jalan. Bangunan yang berada di kaveling sudut memiliki dua orientasi yang menghadap jalan. Akan tetapi Rumah Tinggal Budhi Santoso yang berada di kaveling sudut hanya memiliki satu orientasi muka depan bangunan yang menghadap jalan utama di kawasan tersebut yaitu Jalan Cik Di Tiro. 


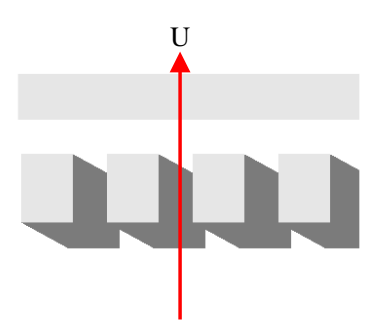

Figur 1. Orientasi Rumah Jawa

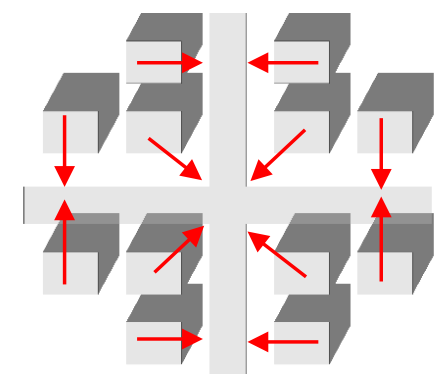

Figur 2. Orientasi Rumah Belanda

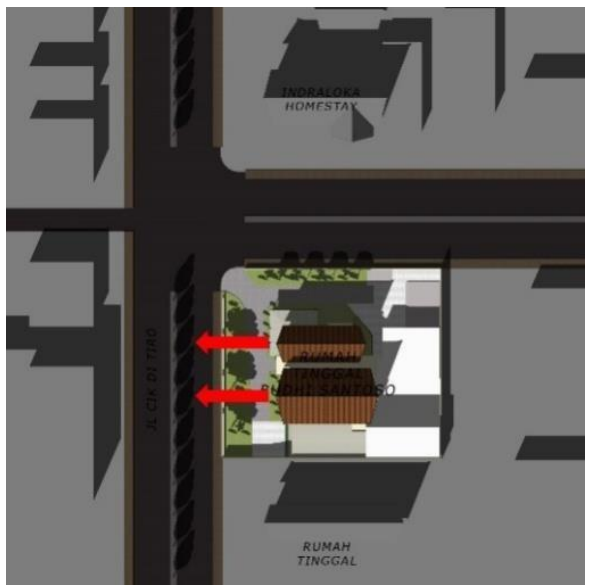

Figur 3. Orientasi Rumah Tinggal Budhi Santoso

\subsubsection{SUMBU}

Sumbu pada Rumah Tinggal Budhi Santoso terbentuk menjadi dua sumbu yaitu sumbu utama dan sumbu sekunder. Sumbu bangunan tidak memiliki patokan arah mata angin sehingga sumbu yang terjadi bebas sesuai dengan arah dan sumbu jalan baik bangunan di kaveling sudut maupun bukan sudut seperti pada bangunan-bangunan Belanda. Sumbu utama terbentuk dari orientasi bangunan yang menghadap arah barat dan sumbu sekunder terbentuk dari teras yang berada di sudut depan bangunan sebagai penyikapan bangunan sudut (corners).

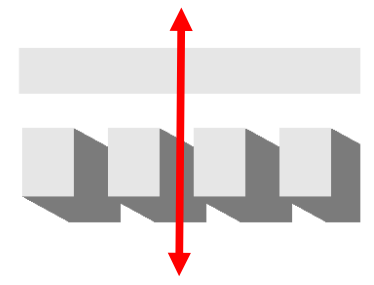

Figur 4. Sumbu Rumah Jawa

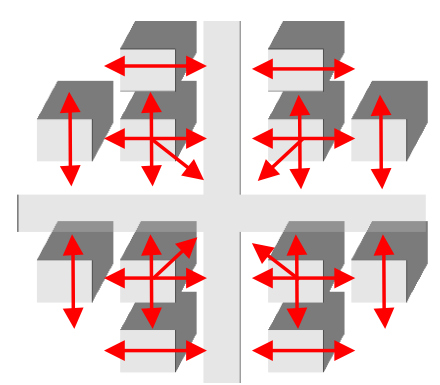

Figur 5. SumbuRumah Belanda 

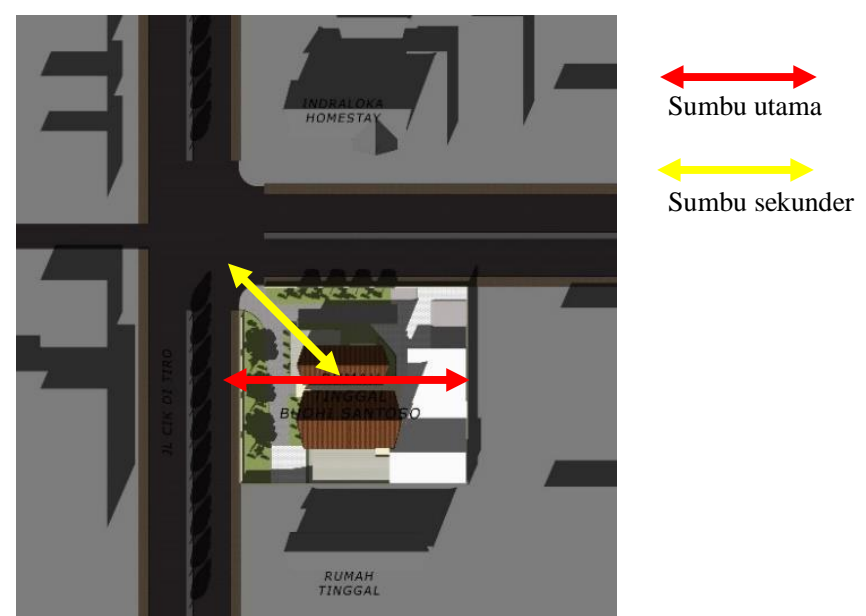

Figur 6. Sumbu Rumah Tinggal Budhi Santoso

\subsubsection{TATANAN}

Tatanan pada Rumah Tinggal Budhi Santoso berada di kaveling sudut pada salah satu persimpangan jalan Cik Di Tiro. Tatanan tersebut merupakan tatanan terbuka dengan bangunan berada di tengah-tengah tapak dan terdapat konsep gardencity dimana sekeliling bangunan merupakan ruang terbuka sebelum adanya penambahan massa akibat bertambahnya kebutuhan aktivitas penghuni.

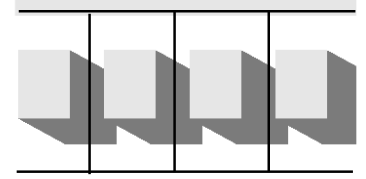

Figur 7. Tatanan massa Rumah Jawa

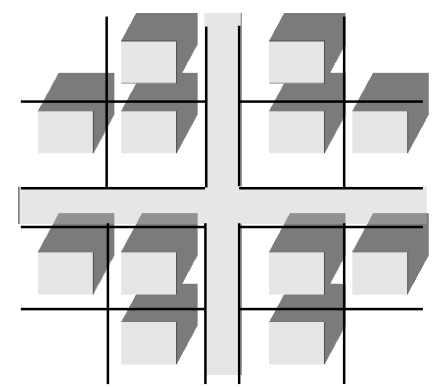

Figur 8. Tatanan massa Rumah

Belanda 


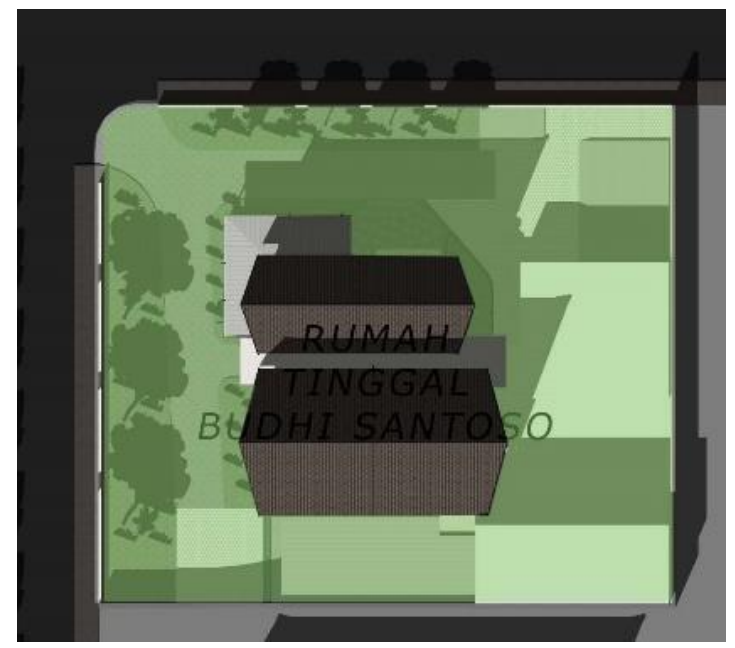

Figur 9. Tatanan massa Rumah Tinggal Budhi Santoso pada tapak

\subsection{BENTUK MASSA RUMAH TINGGAL BUDHI SANTOSO}

\subsubsection{TRANSFORMASI BENTUK}

Rumah Tinggal Budhi Santoso merupakan transformasi bentuk massa yang mengalami campuran bentuk dari arsitektur Belanda dan arsitektur Jawa. Tranformasi bentuk Rumah Tinggal Budhi Santoso merupakan komposisi gubahan bentuk arsitektural dari rumah dalam arsitektur Jawa yang memiliki beberapa massa terlihat dari perbedaan bentuk atapnya. Meskipun gubahan bentuk serupa dengan rumah Jawa akan tetapi elemen bentuk serupa dengan rumah dalam arsitektur Belanda yang dapat dilihat dari kemiringan atap yang curam kurang lebih 60 derajat. Transformasi tersebut menciptakan bentuk yang memiliki proporsi kepala bangunan lebih besar dibanding badan bangunannya.

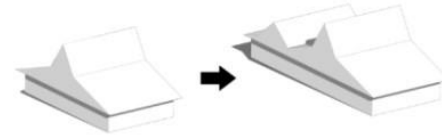

Figur 10.Transformasi Bentuk Rumah Jawa
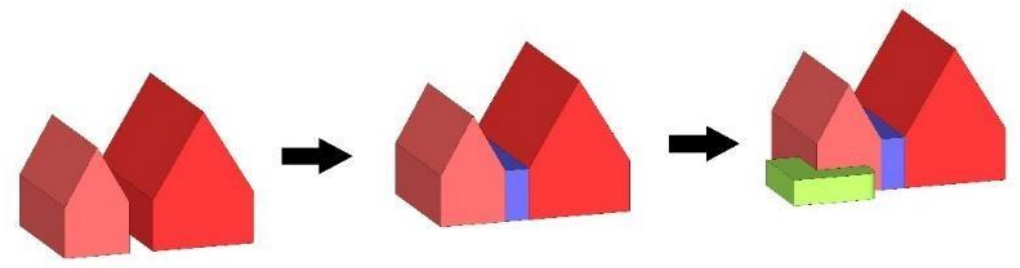

Figur 12. Transformasi Bentuk RumahTinggal Budhi Santoso

\subsubsection{ZONASI}

Zonasi bentuk pada Rumah Tinggal Budhi Santoso merupakan gubahan bentuk yang serupa dengan rumah dalam arsitektur Jawa membentuk adanya beberapa massayang mencerminkan ruang dalamnya berdasarkan aktivitas penghuni; publik, semi-publik, semi-privat, 
dan privat. Massa utama mencerminkan ruang yang dominan atau ruang yang penting, sedangkan massa lainnya menceminkan ruang yang menunjang ruang utama seperti zonasi bentuk rumah tinggal Jawa.
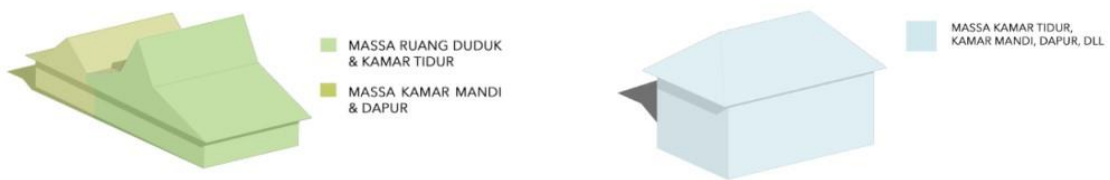

Figur 13. Zonasi Bentuk Rumah Jawa Figur 14. Zonasi Bentuk Rumah Belanda

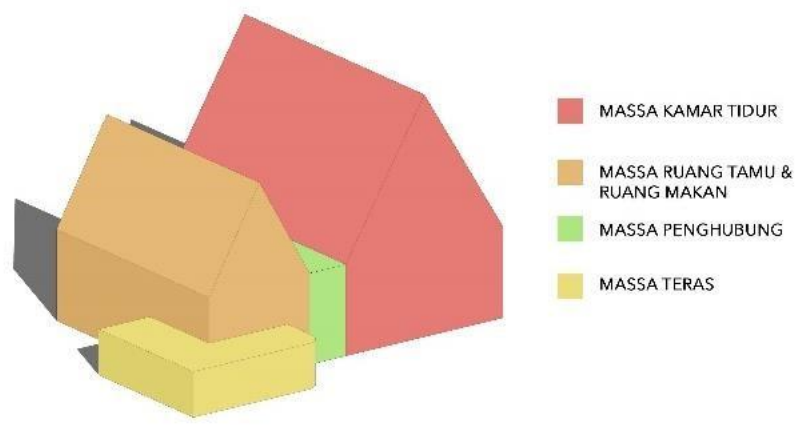

Figur 15. Zonasi Bentuk RumahTinggal Budhi Santoso

Meskipun gubahan bentuk serupa dengan rumah dalam arsitektur Jawa akan tetapi adanya perbedaan dari zona entrance terhadap bentuk bangunannya. Ditinjau dari sudut pandang tampak yang sama, zona entrance Rumah Tinggal Budhi Santoso terletak di tengah-tengah bangunan diantara kedua massa utama (Figur 6) sedangkan zona entrance rumah Jawa berada di samping kiri (Figur 6).

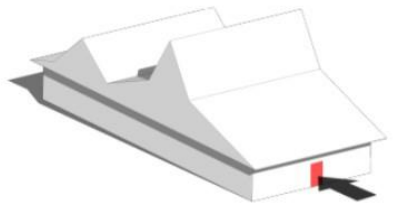

Figur 16. Zona entrance Rumah Jawa

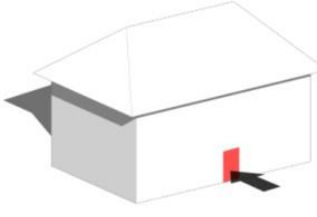

Figur 17. Zona entrance Rumah Belanda 


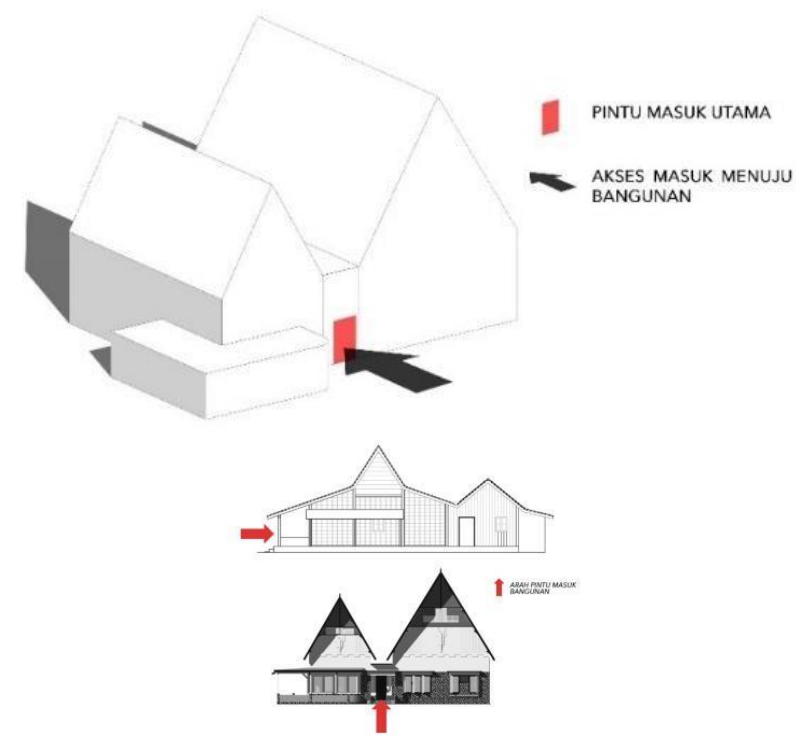

Figur 18.Zonasi entrance pada RumahTinggal Budhi Santoso

\subsubsection{HIRARKI}

Perbedaan bentuk dengan dimensi atau ukuran yang lebih besar merupakan filosofi arsitektur Jawa yang terdapat pada Rumah Tinggal Budhi Santoso mengenai hirarki pada bangunan. Hirarki terlihat pada atap bangunan Rumah Tinggal Budhi Santoso sebagai kepala dari ukuran skala vertikal. Massa utama pada Rumah Tinggal Budhi Santoso dengan fungsi kamar tidur memiliki ukuran yang lebih besar dibanding massa lainnya sehingga menciptakan adanya hirarki pada bentuk bangunan Rumah Tinggal Budhi Santoso.

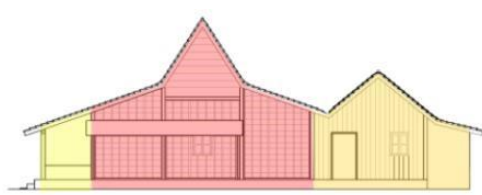

Figur 19.Hirarki pada Rumah Jawa

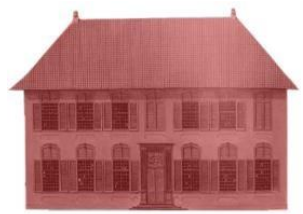

Figur 20.Hirarki pada Rumah

Belanda 


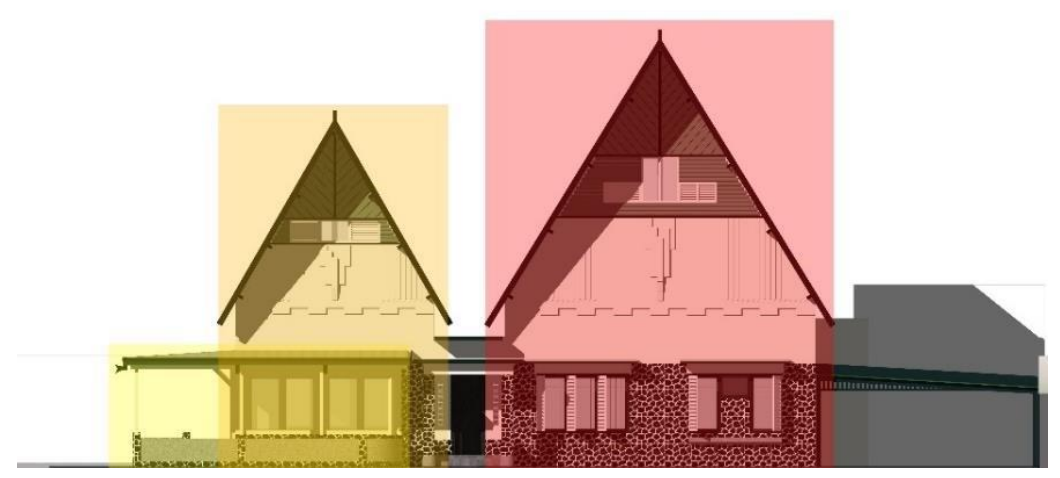

Figur 21. Hirarki pada RumahTinggal Budhi Santoso

\subsubsection{IRAMA/ PENGULANGAN}

Rumah Tinggal Budhi Santoso memiliki pengulangan yang menciptakan suatu pola serupa dengan rumah tinggal Belanda yang terbentuk dari susunan bukaan/jendela. Rumah tinggal Belanda memiliki bukaan/jendela dengan ukuran, proporsi dan skala yang sama satu sama lain pada tampak depan bangunan sehingga membentuk susunan yang teratur dan simetris serta memberikan kesan formal. Sedangkan rumah tinggal Jawa memiliki pengulangan terbentuk dari susunan saka/tiang yang merupakan elemen struktural sebagai struktur utama bangunan.

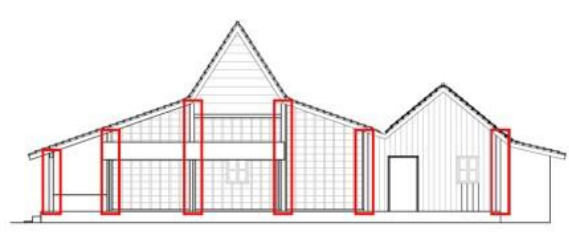

22.Pengulangan pada Rumah Jawa

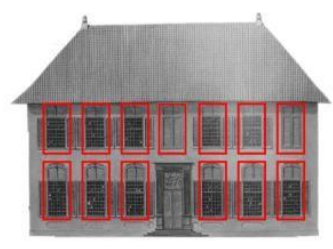

Figur 23.Pengulangan pada Rumah Belanda Figur

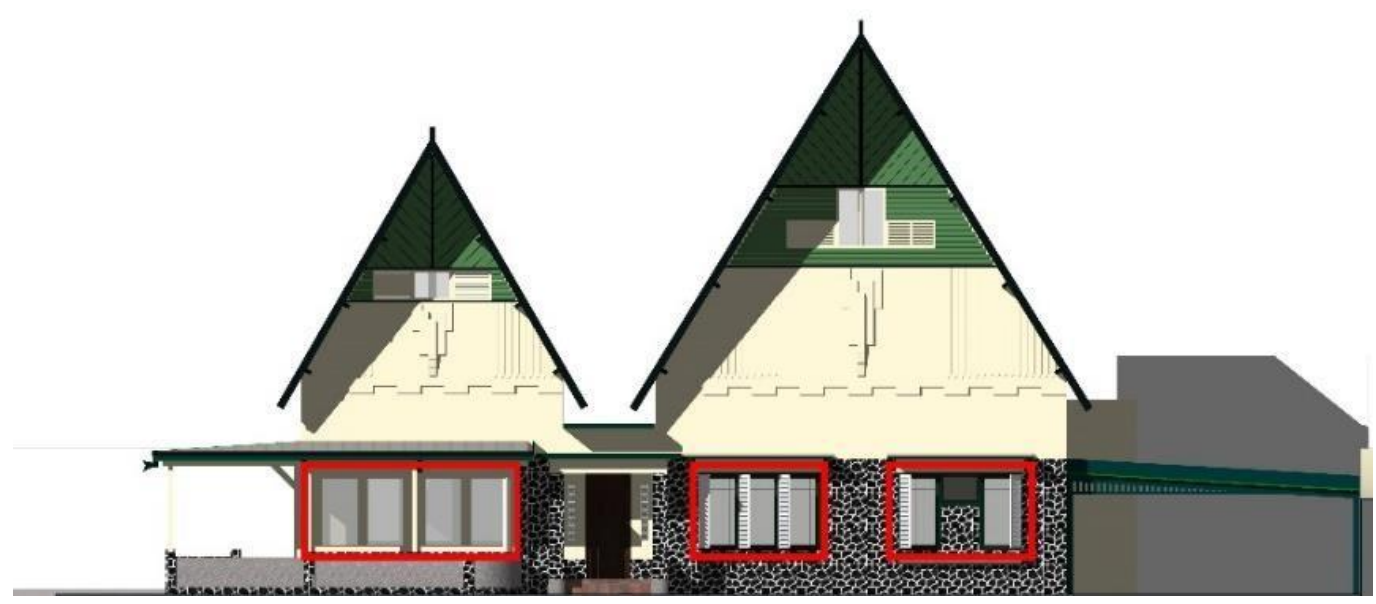

Figur 24.Pengulangan pada Rumah Tinggal Budhi Santoso 


\subsection{TATA RUANG RUMAH TINGGAL BUDHI SANTOSO}

\subsubsection{ORGANISASI RUANG}

Rumah Tinggal Budhi Santoso memiliki koridor/sirkulasi tengah yang diapit dua ruang, ruang yang pertama yaitu ruang tamu dan ruang makan, ruang yang kedua yaitu kamar-kamar tidur (Figur 8) sehingga membentuk organisasi ruang yang memiliki kesan formal dan simetris pada susunan ruangnya serta terdapat kejelasan pada pembagian ruangnya serupa dengan tata ruang arsitektur Belanda.

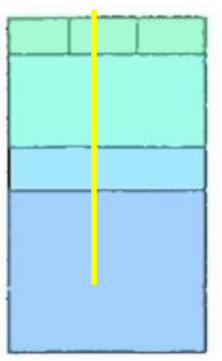

Figur 25.Organisasi ruang Rumah Jawa

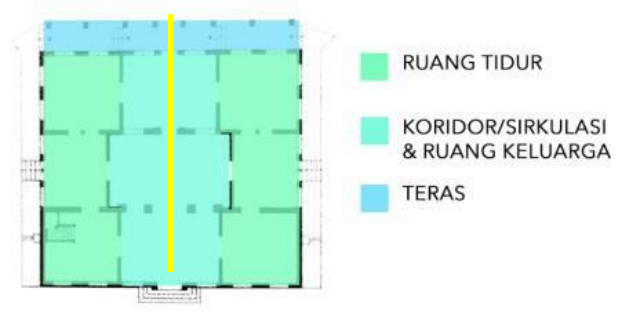

Figur 26. Organisasi ruang Rumah Belanda

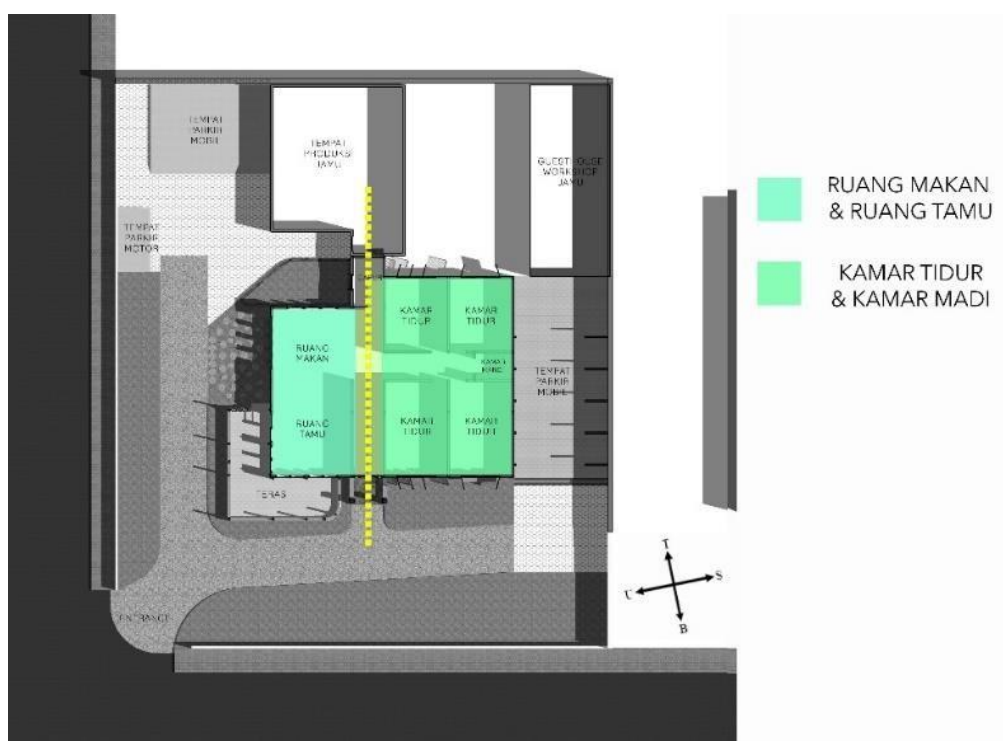

Figur 27. Organisasi Ruang RumahTinggal Budhi Santoso

\subsubsection{ZONASI RUANG}

Rumah Tinggal Budhi Santoso memiliki zonasi dan konsep ruang yang serupa dengan arsitektur Jawa dari ruang depan, ruang tengah, hingga ruang belakang. Zonasi ruang yang ditinjau terdiri dari tiga bagian; public yaitu teras yang mencerminkan pendopo, semi privat yaitu ruang makan dan ruang tamu yang mencerminkan pringgitan, dan privat yaitu kamar tidur yang mencerminkan dalem (Figur 9). 


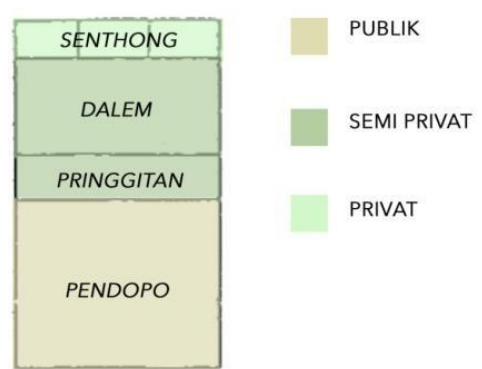

Figur 28. Zonasi ruang Rumah Jawa

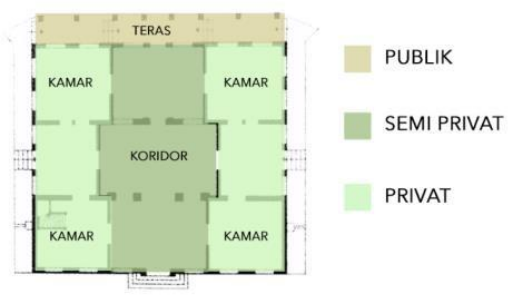

Figur 29.Zonasi ruang Rumah Belanda

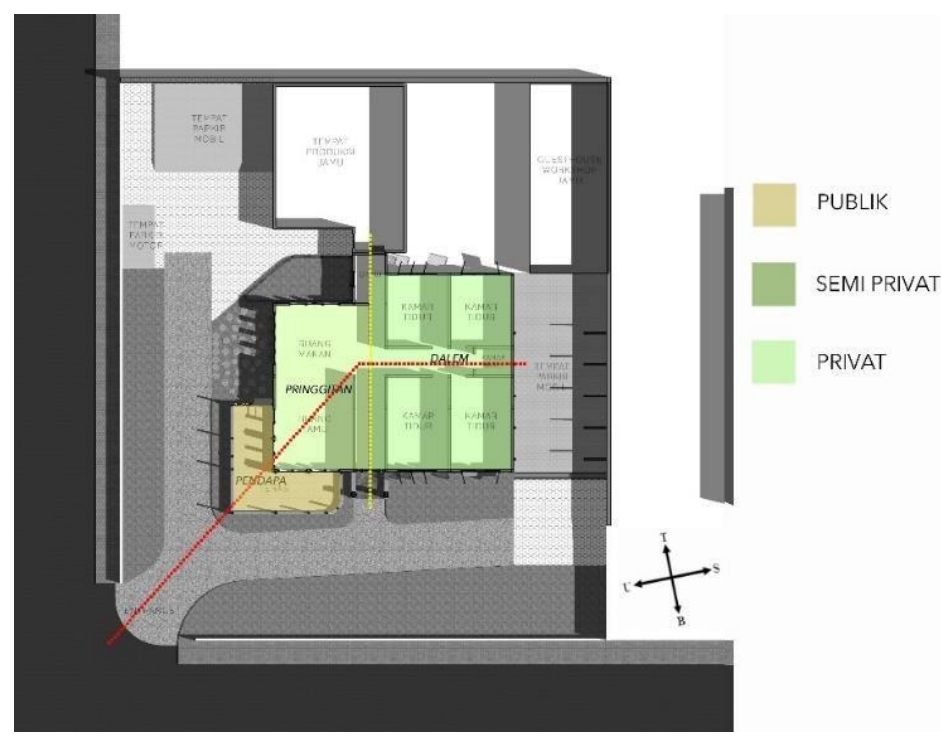

Figur 30. Zonasi Ruang RumahTinggal Budhi Santoso

\subsubsection{SUMBU}

Selain sumbu tapak dan sumbu pada bentuk, bangunan Rumah Tinggal Budhi Santoso memiliki sumbu ruangan yang terdapat pada penataan ruang bangunan sesuai dengan bentuk tata ruang secara dua dimensi. Sumbu ruangan yang terjadi pada Rumah Tinggal Budhi Santoso serupa dengan rumah tinggal Jawa dan rumah tinggal Belanda dimana sumbu utama berada di tengahtengah bangunan.

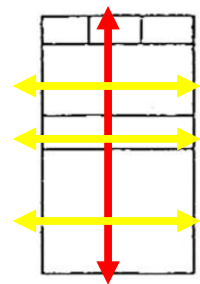

Figur 31. Sumbu ruang Rumah Jawa

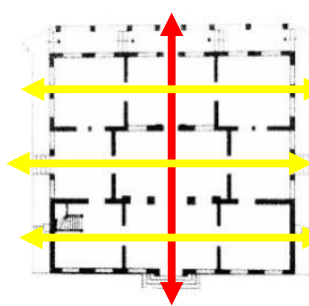

Figur 32. Sumbu ruang Rumah Belanda 


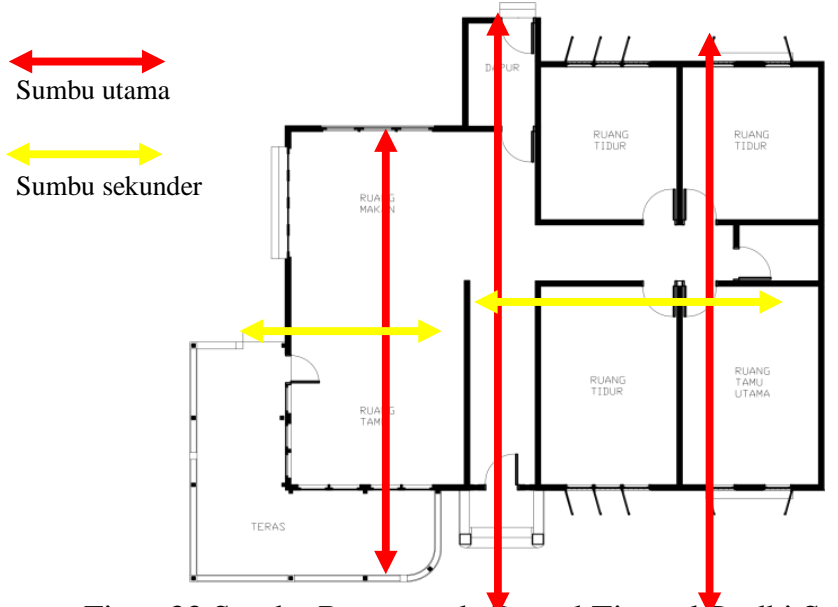

Figur 33.Sumbu Ruang pada RumahTinggal Budhi Santoso

\subsubsection{SIRKULASI}

Sirkulasi utama pada Rumah Tinggal Budhi Santoso berada di tengah-tengah bangunan yang terbentuk dari sumbu ruangan seperti sirkulasi pada rumah tinggal Jawa maupun rumah tinggal Belanda. Akan tetapi sirkulasi pada Rumah Tinggal Budhi Santoso lebih serupa dengan sirkulasi rumah tinggal Belanda dimana sirkulasi utama berada di tengah dan memiliki sirkulasi sekunder ke kiri dan kanan menuju ruangan-ruangan yang terbagi akibat sirkulasi utama tersebut.

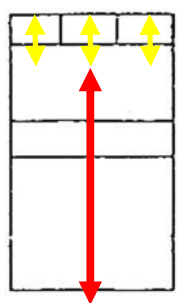

Figur 34. Sirkulasi pada Rumah Jawa

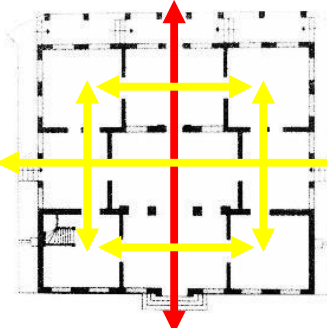

Figur 35. Sirkulasi pada Rumah Jawa

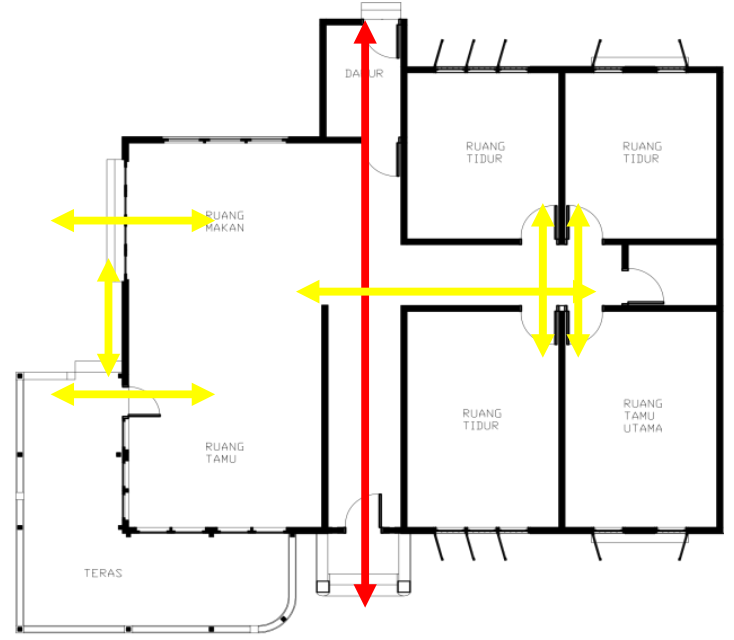

Figur 36.Sirkulasi Ruang RumahTinggal Budhi Santoso 


\subsection{ELEMEN PELINGKUP RUMAH TINGGAL BUDHI SANTOSO}

\subsubsection{STRUKTURAL}

Sistem struktur pada Rumah Tinggal Budhi Santoso menggunakan sistem rangka kolom dan balok secara keseluruhan. Jika dikaitkan dengan sistem struktur dalam arsitektur Jawa dan arsitektur Belanda, Rumah Tinggal Budhi Santoso memiliki sistem struktur yang memiliki pengaruh dari keduanya. Sistem struktur pada Rumah Tinggal Budhi Santoso secara keseluruhan menggunakan sistem struktur rangka. Penggunaan sistem struktur rangka terlihat jelas pada bagian struktur kepala bangunan dengan rangka kuda-kuda yang berasal dari arsitektur Belanda dan badan bangunan menggunakan sistem rangka kolom dan balok yang berasal dari arsitektur Jawa.

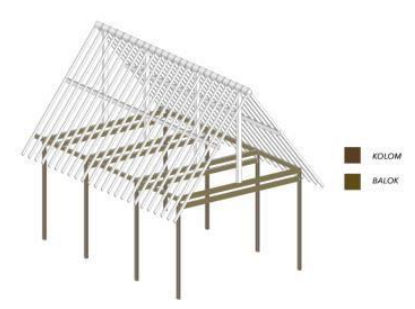

Figur 37. Sistem struktur Rumah Jawa

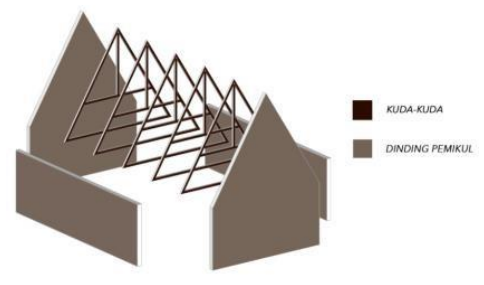

Figur 38. Sistem struktur Rumah Belanda

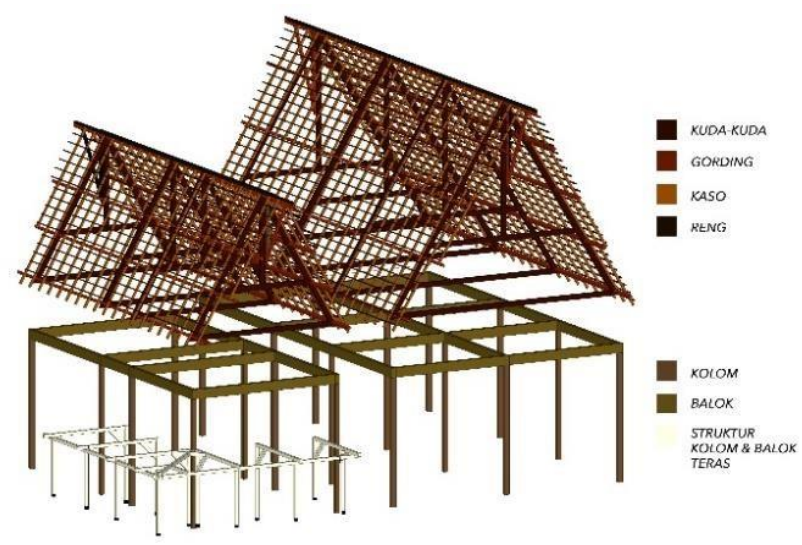

Figur 39. Sistem Struktur Rumah Tinggal Budhi Santoso

\subsubsection{NON STRUKTURAL}

Bagian kepala bangunan Rumah Tinggal Budhi Santoso terdiri dari atap dan plafon. Atap bangunan memiliki bentuk serupa dengan ukuran yang berbeda sehingga menciptakan hirarki pada bentuk atapnya seperti yang terdapat dalam filosofi arsitektur Jawa. Akan tetapi ruang atap tidak terlihat dari ruang dalam karena langit-langit bangunan tertutup oleh plafon. Ruang atap tidak digunakan menjadi ruang yang fungsional hanya menjadi ruang sirkulasi udara. 


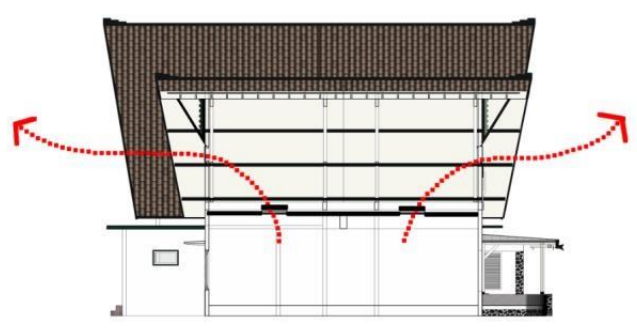

Figur 40 Atap Rumah Tinggal Budhi Santoso

Bagian badan bangunan tidak menggunakan dinding struktural atau dinding pemikul seperti rumah tinggal Belanda akan tetapi menggunakan dinding pengisi yang terbuat dari batu bata. Pintu utama memiliki letak yang serupa dengan rumah tinggal Belanda dan Jawa yaitu berada di tengahtengah bangunan dengan dimensi pintu yang standar tidak seperti rumah Belanda yang memiliki pintu dengan skala monumental. Bukaan/jendela pada bangunan memiliki dua jenis yang berbeda, yang pertama jendela dengan bahan kusen kayu dan kaca seperti jendela rumah Belanda yang berada di massa utama ruang tamu dan ruang makan dan jendela dengan bahan kusen kayu, kaca, dan terdapat krepyak kayu seperti jendela rumah Jawa yang berada di massa utama ruangruang tidur. Meskipun terdapat jenis yang berbeda tetapi jendela tersebut memiliki ukuran yang hampir sama. Lantai Rumah Tinggal Budhi Santoso menggunakan penutup lantai teraso dengan ukuran 20x20 cm tidak seperti rumah tradisional Jawa pada umumnya yang tidak memiliki perkerasan pada permukaan lantainya.

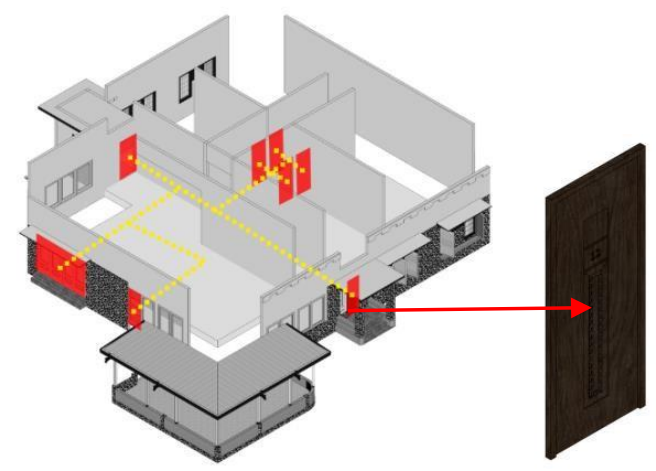

Figur 41. Pintu Rumah Tinggal Budhi Santoso

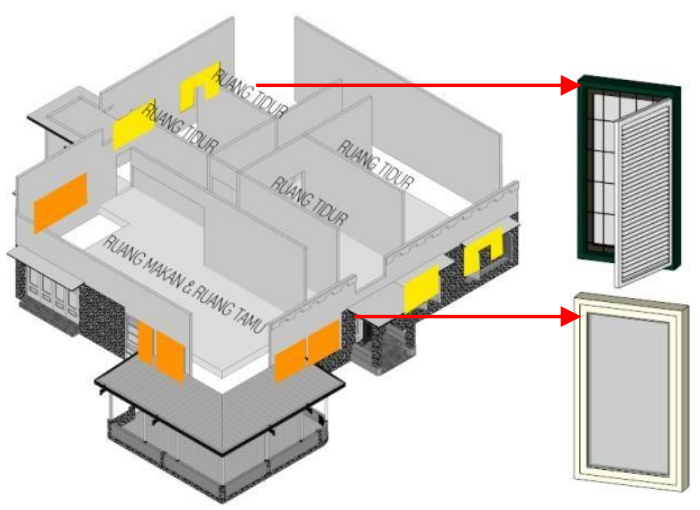

Figur 42. Jendela Rumah Tinggal Budhi Santoso 


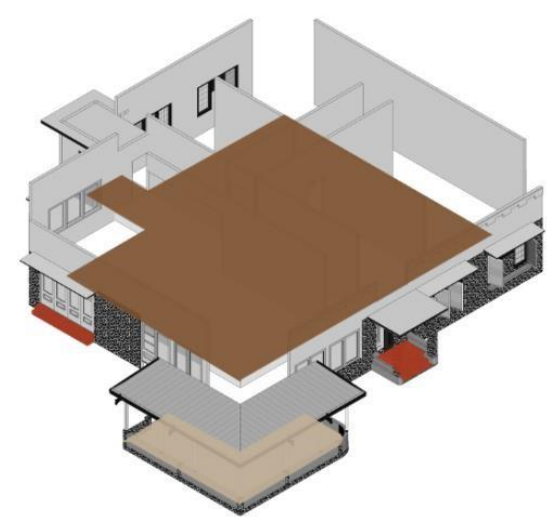

Figur 43. Lantai Rumah Tinggal Budhi Santoso

\subsection{ORNAMEN}

Ornamen yang ditemukan pada Rumah Tinggal Budhi Santoso terdapat pada bagian kepala bangunan berupa lapisan-lapisan kayu yang berwarna hijau serta ukiran pada dinding atap. Ornamen lainnya terdapat pada pintu masuk utama bangunan yang memiliki ukiran. Hiasan tersebut merupakan bagian dari ornamen artdeco yang berasal dari negeri eropa. Pada bagian interior Rumah Tinggal Budhi Santoso tidak ditemukan ornamen atau ragam hias baik Jawa maupun Belanda.

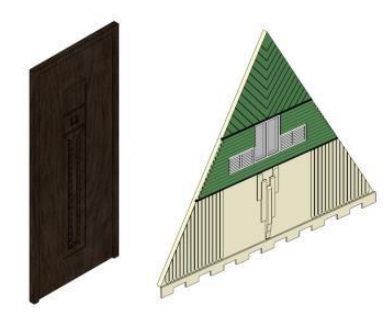

Figur 44. Ornamen pada Rumah Tinggal Budhi Santoso

\section{KESIMPULAN}

Bagaimanakah wujud akulturasi arsitektur pada bangunan Rumah Tinggal Budhi Santoso di Yogyakarta? Wujud Akulturasi pada bangunan Rumah Tinggal Budhi Santoso di Yogyakarta merupakan wujud akulturasi arsitektur bangunan indis yang mengalami perpaduan arsitektur Belanda dengan arsitektur Jawa. Wujud akulturasi arsitektur pada penelitian ini ditinjau dari berbagai aspek yaitu tapak, bentuk massa, tata ruang, sistem struktur, elemen pelingkup (struktural dan non struktural) dan ornamen.

Tapak pada Rumah Tinggal Budhi Santoso yang berada di kaveling sudut memiliki pengaruh arsitektur Belanda, tetapi orientasi bangunan hanya mengarah ke satu sisi jalan saja yang menghadap arah barat sebagai muka depan bangunan, bukan mengikuti sumbu kosmis UtaraSelatan seperti filosofis penataan bangunan dalam arsitektur Jawa.

Bentuk massa pada Rumah Tinggal Budhi Santoso merupakan gubahan bentuk rumah Jawa yang terbagi menjadi beberapa massa tetapi memiliki elemen bentuk rumah Belanda dengan 
kemiringan atap yang curam kurang lebih 60 derajat sehingga membentuk proporsi kepala bangunan yang lebih besar dibanding badan bangunan.

Tata ruang pada Rumah Tinggal Budhi Santoso memiliki organisasi ruang yang hampir serupa dengan tata ruang arsitektur Belanda dengan adanya koridor di tengah ruangan dan membagi ruangan kiri dan kanan. Akan tetapi Rumah Tinggal Budhi Santoso memiliki zonasi ruang yang serupa dengan tata ruang arsitektur Jawa dengan adanya teras sebagai pendopo yang memiliki arah ke sudut simpang jalan, ruang tamu dan ruang makan sebagai pringgitan, dan ruang kamar tidur sebagai dalem.

Elemen pelingkup struktural pada Rumah Tinggal Budhi Santoso merupakan sistem struktur rangka yang memiliki perpaduan dari sistem struktur Belanda dengan menggunakan rangka atap kuda-kuda dan sistem struktur Jawa dengan menggunakan struktur kolom/tiang dan balok. Elemen Pelingkup non struktural juga mengalami percampuran dari arsitektur Belanda dan arsitektur Jawa. Pada bagian kepala bangunan terdapat bukaan/jendela seperti pada bangunan Belanda yang difungsikan sebagai ventilasi udara. Pada bagian badan bangunan, dinding bangunan merupakan dinding pengisi yang dilapis batu kali akibat faktor iklim dan lingkungan agar dinding tidak kotor yang merupakan ciri arsitektur Indis.

Ornamen pada Rumah Tinggal Budhi Santoso terletak di bagian dinding atap dan pintu utama bangunan. Ornamen tersebut merupakan ornament yang baru dan tidak terdapat dalam ragam hias Jawa maupun ragam hias Belanda.

Kesimpulan akhir penelitian ini bahwa terdapat aspek yang didominasi oleh pengaruh arsitektur Belanda atau arsitektur Jawa dan atau pencampuran dari keduanya. Aspek tapak lebih banyak mendapatkan pengaruh dari arsitektur Belanda, sedangkan aspek-aspek lainnya seperti bentuk massa, tata ruang, sistem struktur, elemen pelingkup dan ornament telah mengalami pencampuran dari keduanya dan membentuk arsitektur yang baru.

\section{DAFTAR PUSTAKA}

Ching, Francis D. K. (1996). Arsitektur Bentuk, Ruang dan Tatanan. Jakarta: Erlangga.

Evensen, Thomas. (1987). ArchetypesinArchitecture. Norwegia: Norwegian University Press.

Koentjaraningrat. (2005). Pengantar Antropologi. Bina Estetika: Jakarta.

Salura, Purnama. (2010). Arsitektur yang Membodohkan. CSS Publishing: Bandung.

Haviland, William A. (1988a). Antropologi, Jilid I, Jakarta: Erlangga.

Sumalyo. (1993). Arsitektur Kolonial Belanda di Indonesia. Yogyakarta: Gajah Mada University Press.

Jessup, Helen. (1988). Netherlands Architecture in Indonesia 1900-1942. Courtland Art: London.

Siregar, Sandi. (1990). Bandung The Architecture of the City in Development. Belgia: Disertasi pada K.U. Leuven.

Miksic, John. (2003). Indonesian Heritage. Archipelago Press.

Soekiman, Djoko. (2000). Kebudayaan Indis dan Gaya Hidup Masyarakat Pendukungnya di Jawa (Abad XVII - Media Abad X). Yogyakarta: Bentang.

Handinoto. (1996). Perkembangan Kota \& Arsitektur Kolonial Belanda di Surabaya (1870 - 1940). Yogyakarta: Andi Ofset.

Handinoto. (1996). American Vernacular Design. Jakarta: Dimensi. 
Fauzy, Bachtiar. (2012). Konsep Kearifan Lokal Dalam Arsitektur Rumah Tinggal Masyarakat Kota Pesisir Utara Jawa. LPPM. Arsitektur Unpar.

Frick, Heinz. (1997). Pola Struktural dan Teknik Bangunan di Indonesia. Yogyakarta: Kanisius.

Dakung, Sugiarto. (1997). Arsitektur Tradisional Daerah Istimewa Yogyakarta. Yogyakarta: Andi Ofset.

Arkanudin, H. (2012). Akulturasi Sebagai Mekanisme Perubahan Kebudayaan. Retrieved Maret 14, 2016 from http://prof-arkan.blogspot.co.id/2012/04/akulturasi-sebagai-mekanisme perubahan.html

Komosa, Susanne. (2009). The Transformation of the Dutch Urban Block in Relation to the Public Realm; Model, Rule and Ideal. Retrieved Maret 14, 2016 from repository.tudelft.nl/assets/uuid:d3f502e3-6152-4ee3-a93b.../komossa_totaal.pd 